ISSN: 2302-8556

E-Jurnal Akuntansi Universitas Udayana

Vol.23.1. April (2018): 351-378

DOI: https://doi.org/10.24843/EJA.2018.v23.i01.p14

\title{
Pengaruh Pemanfaatan dan Relevansi Teknologi Informasi serta Efektivitas Sistem Informasi Akuntansi pada Kinerja Karyawan
}

\author{
Luh Putu Eka Agustina Pratiwi ${ }^{1}$ \\ Ida Bagus Dharmadiaksa ${ }^{2}$ \\ ${ }^{1}$ Fakultas Ekonomi dan Bisnis Universitas Udayana (Unud), Bali, Indonesia \\ email:ekaagustinapratiwi@gmail.com/telp: +62 81338553350 \\ ${ }^{2}$ Fakultas Ekonomi dan Bisnis Universitas Udayana (Unud), Bali, Indonesia
}

\begin{abstract}
ABSTRAK
Penelitian ini bertujuan untuk mengetahui pengaruh pemanfaatan teknologi informasi, relevansi teknologi informasi, kepuasan sistem informasi akuntansi, dan efektivitas sistem informasi akuntansi pada kinerja karyawan. Penelitian ini dilakukan pada 51 BPR yang tersebar di Kabupaten Badung. Sampel yang digunakan dalam penelitian ini adalah sebanyak 101 responden. Metode penentuan sampel yang digunakan pada penelitian ini yaitu metode purposive sampling. Teknik analisis data yang digunakan dalam penelitian ini yaitu analisis regresi linear berganda. Hasil penelitian menunjukan bahwa semua variabel bebas yang digunakan dalam penilitian ini berpengaruh positif terhadap kinerja karyawan. Hal ini berarti pemanfaatan teknologi informasi, relevansi teknologi informasi, kepuasan sistem informasi akuntansi dan efektivitas sistem informasi akuntansi bermanfaat dalam meningkatkan kinerja karyawan.
\end{abstract}

Kata Kunci: Kinerja karyawan, pemanfaatan teknologi informasi, relevansi teknologi informasi, kepuasan SIA, efektivitas SIA

\begin{abstract}
This study aims to analyze influence of information technology utilization, information technology relevance, accountancy information system satisfaction, and effectiveness of accounting information system on employee performance. This research was conducted on 51 BPR spread in Badung regency. The sample used in this research is counted 101 respondents. Sampling method used in this research is purposive sampling method. Data analysis technique used in this research is multiple linear regression analysis. The results showed that all the independent variables used in this study have a positive effect on employee performance. This means the use of information technology, the relevance of information technology, accounting information system satisfaction and the effectiveness of accounting information systems useful in improving employee performance.
\end{abstract}

Keywords: Employee performance, utilization of information technology, information technology relevance, AIS satisfaction, effectiveness of AIS 
Luh Putu Eka Agustina Pratiwi dan Ida Bagus Dharmadiaksa. Pengaruh...

\section{PENDAHULUAN}

Pada eraglobalisasi saat ini, setiap perusahaan dituntut untuk melakukan perubahan di bidang teknologi sehingga nantinya mampu memberikan peluang untuk meningkatkan keunggulan kompetitif. Penggunaan teknologi informasi dalam menunjang penerapan sistem informasi pada suatu perusahan membawa pengaruh terhadap kinerja karyawan. Kinerja karyawan menjadi salah satu faktor yang berperan penting dalam meningkatkan kualitas dan produktivitas perusahan. Kinerja karyawan merupakan pencapaian atau hasil kerja seseorang yang secara keseluruhan selama kurun waktu tertentu dalam melaksanakan tugas yang dibandingkan dengan berbagai kemungkinan, seperti standar hasil kerja, target atau sasaran atau kriteria yang telah ditetapkan terlebih dahulu dan telah disepakati bersama.

Keberhasilan sebuah perusahan bisa dilihat dari kinerja seorang individu dalam memanfaatkan teknologi sistem informasi untuk memberikan kemudahan bagi mereka dalam menyelesaikan tugasnya, yang pada akhir berdampak pada peningkatan kinerja perusahan itu sendiri. Menurut Arsiningsih (2015) menjelaskan kinerja karyawan sangat berpengaruh dalam pengoperasian sistem informasi sebuah perusahaan. Salah satu sistem informasi yang digunakan dalam sebuah perusahan adalah sistem informasi akuntansi. Sistem informasi akuntansi adalah sebuah sistem yang terkomputerisasi yang berperan untuk menyiapkan informasi finansial dan juga informasi yang diperoleh dalam bentuk kegiatan pengumpulan dan pengolahan transaksi. Sistem informasi akuntansi merupakan variabel paling mempengaruhi kinerja keuangan (Soudani, 2012). Sistem 
informasi akuntansi ini merupakan sebuah peluang khususnya bagi para pebisnis dalam rangka optimalisasi efisiensi dan efektivitas dalam pengambilan keputusan sehingga memungkinkan perusahaan memperoleh keunggulan kompetitif (Edison et al., 2012).

Efektivitas merupakan suatu hasil atas pencapaian target yang telah ditetapkan. Efektivitas sistem informasi akuntansi mengukur sejauh mana target yang dicapai dari suatu kumpulan sumber daya yang diatur untuk mengumpulkan, memproses, dan menyimpan data elektronik. Kemudian di olah menjadi sebuah informasi yang berguna dan menyajikan laporan formal yang diperlukan dengan baik secara kualitas maupun waktu, yang pada akhirnya akan digunakan dalam pengambilan keputusan bagi sebuah perusahan. Penelitian mengenai pengaruh efektivitas sistem informasi akuntansi pada kinerja karyawan telah dilakukan sebelumnya oleh Pangeso (2014), Astuti (2014), dan Mercika (2015) menyatakan efektivitas sistem informasi akuntansi berpengaruh positif dan signifikan terhadap kinerja karyawan maupun perusahaan. Namun disisi lain, penelitian yang dilakukan oleh penelitian Urquia et al. (2010), Kouser et al. (2011), dan Kharuddin et al. (2010) menunjukkan bahwa pengadopsian SIAtidak dapat meningkatkan kinerja, profitabilitas, dan efisiensi operasi.

Penelitian mengenai pengaruh pemanfaatan teknologi informasi pada kinerja karyawan telah dilakukan sebelumnya oleh Wahyuni (2014), dan Kasandra (2014) menunjukkan pemanfaatanteknologi informasi berpengaruh positif dan signifikan terhadap kinerja individu. Namun, penelitian yang berbeda 
Luh Putu Eka Agustina Pratiwi dan Ida Bagus Dharmadiaksa. Pengaruh...

dilakukan oleh Tjhai (2003) dan Jurnali (2002) dengan hasilnya yang menunjukan bahwa pemanfaatan teknologi informasi tidak mempengaruhi kinerja individual.

Relevansi teknologi informasi atau kesesuaian tugas dengan teknologi informasi sangat berperngaruh terhadap kinerja individu pada suatu perusahan. Goodhue dan Thompson (1995) menyatakan kecocokan tugas dengan teknologi informasi akan mengarahkan individual untuk mencapai kinerja yang lebih baik. Maka dari itu, evaluasi pemakai menjadi tolak ukur untuk keberhasilan pelaksanaan kualitas jasa sistem informasi yang dihubungkan dalam relevansi teknologi informasi dengan tugas.

Pemanfaatan teknologi sistem informasi dalam menunjang sistem informasi membawa pengaruh terhadap hampir semua aspek dalam pengelolaan keuangan perbankan (Utami, 2015). BPR juga merupakan bank dimana sebagai lembaga keuangan tentu membutuhkan laporan keuangan sebagai sarana untuk pertanggungjawaban kepada pemangku kepentingan (stakeholder). Untuk melaksanakan perannya dalam menyediakan laporan keuangan maka kegiatan operasional yang ada pada BPR harus didukung dengan sistem informasi akuntansi untuk dapat mempermudah BPR dalam menghasilkan berbagai jenis laporan keuangan yang dibutuhkan.

\section{Tabel 1}

Perkembangan Kredit BPR/ BPRS di Kabupaten Badung Tahun 2012 - 2016

\begin{tabular}{cccc}
\hline No & Tahun & Total Kredit (Rp) & Pertumbuhan (\%) \\
\hline 1 & 2012 & $1,265,854,283$ & 29 \\
2 & 2013 & $1,499,432,658$ & 18 \\
3 & 2014 & $1,809,455,548$ & 21 \\
4 & 2015 & $2,048,751,808$ & 13 \\
5 & 2016 & $2,268,261,394$ & 11 \\
Rata & Rata & $1,778,351,138$ & 18.4 \\
\multicolumn{5}{l}{ Sumber: }
\end{tabular}


Berdasarkan Tabel 1 menunjukkan BPR di Kabupaten Badung memiliki rata-rata kredit sebesar $1,778,351,138$ rupiah dan rata-rata pertumbuhan sebesar 18.4\%. Namun, pertumbuhan persentase kredit dari tahun 2012-2016 yang terjadi pada BPR di Kabupaten Badung menunjukkan pertumbuhan fluktuatif yang cenderung menurun. Ini berarti kinerja dari BPR di Kabupaten Badung memiliki kinerja yang kurang optimal. Hal itu bisa terjadi dari faktor pemasaran yang lemah sehingga BPR kurang mendapat kepercayaan dari masyarakat, maupun kinerja yang disebabkan dari faktor internal BPR itu sendiri. Faktor internal itu sendiri bisa dilihat dari keandalan sebuah BPR dalam menjalankan infrastrukturnya yang mengharuskan karyawan menggunakan teknologi informasi dan/ atau sistem informasi akuntansi untuk dapat mepertahankan kepercayaan masyarakat dan memberikan kemudahan akses kredit.

Berdasarkan hasil penelitian terdahulu, masih terdapat perbedaanperbedaan hasil penelitian, sehingga peneliti termotivasi untuk meneliti kembali dengan mereplikasi penelitian tentang pengaruh pemanfaatan dan relevansi teknologi informasi serta efektifitas sistem informasi akuntansi pada kinerja karyawan BPR di Kabupaten Badung. Perbedaan penelitian ini dengan penelitian terdahulu 1) Penelitian ini menggunakan BPR di Kabupaten Badung sebagai lokasi penelitian karena Kabupaten Badung merupakan kabupaten yang memiliki tingkat Pendapatan Asli Daerah tertinggi di Bali. Selain itu, Kabupaten Badung memiliki jumlah BPR terbanyak dibandingkan kabupaten lainnya yang ada di Bali berdasarkan data yang diperoleh dari Perbarindo; 2) Penelitian ini menghilangkan variabel independen kepercayaan teknologi informasi dengan kepuasan sistem 
Luh Putu Eka Agustina Pratiwi dan Ida Bagus Dharmadiaksa. Pengaruh...

informasi akuntansi. Berdasarkan latar belakang diatas, maka peneliti tertarik untuk melakukan penelitian ini.

Berdasarkan pemaparan latar belakang tersebut, maka dapat dirumuskan beberapa pokok masalah yakni: 1) Apakah Pemanfaatan Teknologi Informasi berpengaruh pada Kinerja Karyawan BPR di Kabupaten Badung?; 2) Apakah Relevansi Teknologi Informasi berpengaruh pada Kinerja Karyawan BPR di Kabupaten Badung? 3) Apakah Kepuasan Sistem Informasi Akuntansi berpengaruh pada Kinerja Karyawan BPR di Kabupaten Badung? 4) Apakah Efektivitas Sistem Informasi Akuntansi berpengaruh pada Kinerja Karyawan BPR di Kabupaten Badung? Adapun tujuan dilakukannya penelitian ini yaitu untuk menguji pengaruh Pemanfaatan Teknologi Informasi, Relevansi Teknologi Informasi, Kepuasan Sistem Informasi Akuntansi dan Efektivitas Sistem Informasi Akuntansi pada Kinerja Karyawan BPR di Kabupaten Badung. Penelitian ini memiliki dua macam manfaat yang meliputi manfaat teoritis yaitu hasil penelitian ini mampu memberikan pemahaman bagaiamana teori Technology Acceptance Model (TAM) dan Technology-to-performance Chain (TPC) yang diterapkan dapat menilai kinerja karyawan BPR di Kabupaten Badung. Serta secara praktis Penelitian ini dapat memberikan sumbangan pemikiran dan masukan bagi BPR yang ada di Kabupaten Badung tentang pemanfaatan teknologi informasi, relevansi teknologi informasi, kepuasan sistem informasi akuntansi, dan efektivitas sistem informasi akuntansi dalam mengevaluasi kinerja karyawan.

TAM (Technology Acceptance Model), yang diperkenalkan pertama kali oleh Davis pada tahun 1989 merupakan teori tentang penggunaan sistem teknologi 
informasi yang menjelaskan bahwa penggunaan sistem informasi akan dipengaruhi oleh variabel kemanfaatan (usefulness) dan variabel kemudahan pemakaian (ease of use). Model TAM diadopsi dari model Theory of Reasoned Action (TRA) yang mejelaskan bahwa penggunaan komputer ditentukan oleh sikap individual terhadap penggunaan sistem dan perasaan kegunaan. Hubungan antara penggunaan sistem dan tujuan perilaku yang digambarkan dalam TAM menunjukkan secara tidak langsung bentuk - bentuk tujuan individu untuk melakukan tindakan positif.

Technology-to-PerformanceChain (TPC) merupakan suatu model komprehensif yang dibangun dari dua aliran penelitian yang saling melengkapi, yaitu sikap pemakai (user attitude) sebagai predictor dari pemakaian (utilization) dan kesesuaian tugas teknologi (task-technology fit) sebagai predictor dari kinerja (Jogiyanto, 2007). Inti dari model ini adalah agar suatu teknologi informasi memberikan dampak positif terhadap kinerja individual maka teknologi tersebut harus dimanfaatkan dan teknologi tersebut harus sesuai dengan jenis pekerjaan yang dilakukan (Agustiani, 2010).

Penelitian Utari (2012) dan Astuti (2014) menyatakan bahwa pemanfaatan teknologi informasi berpengaruh positif terhadap kinerja individual. Diperkuat oleh peneletian Kasandra (2014) menyatakan bahwa pemanfaatan teknologi informasi berpengaruh signifikan pada kinerja karyawan. Berdasarkan uraian diatas, maka hipotesis dapat rumuskan sebagaiberikut:

$\mathrm{H}_{1}$ : Pemanfaatan teknologi informasi berpengaruh positif pada kinerja karyawan 
Luh Putu Eka Agustina Pratiwi dan Ida Bagus Dharmadiaksa. Pengaruh...

Penelitian Ashianti (2013) menyatakan kesesuaian tugas-teknologi berpengaruh positif terhadap kinerja individu. Astuti (2014) menyatakan bahwa kesesuaian tugas dengan teknologi informasi berpengaruh positif terhadap kinerja karyawan. Semakin relevan tugas yang diselesaikan dengan kemampuan seorang karyawan dan teknologi yang digunakan, maka semakin meningkat kinerja karyawan. Berdasarkan uraian diatas, maka hipotesis yang dirumuskan:

$\mathrm{H}_{2}$ : Relevansi teknologi informasi berpengaruh positif pada kinerja karyawan BPR di Kabupaten Badung

Penelitian yang dilakukan oleh Istianingsih dan utami (2009) dan Raminda (2014), yang menunjukkan bahwa kepuasan pengguna berpengaruh positif dan signifikan terhadap kinerja individu. Wijayanti (2013) menyatakan bahwa kepuasan pengguna dari sistem informasi akuntansi berpengaruh positif dan signifikan terhadap kinerja individual. Berdasarkan uraian diatas, maka hipotesis dapat dirumuskan sebagai berikut.

$\mathrm{H}_{3}$ : Kepuasan sistem informasi akuntansi berpengaruh positif pada kinerja karyawan BPR di Kabupaten Badung

Penelitian yang dilakukan oleh Suratini (2015) bahwa efektivitas sistem informasi akuntansi berpengaruh positif dan signifikan terhadap kinerja individual. Penelitian yang dilakukan oleh Awesejo (2013) menyatakan efektivitas penggunaan berpengaruh positif terhadap kinerja individual pengguna SIA. Hal ini diperkuat dengan penelitian yang dilakukan oleh Utari (2012) dan Arsiningsih (2015) menunjukkan bahwa ada pengaruh positif antara efektivitas sistem informasi terhadap kinerja individual. Berdasarkan uraian di atas, maka hipotesis dapat dirumuskan sebagai berikut. 
$\mathrm{H}_{4}$ : Efektifitas sistem informasi akuntansi berpengaruh positif pada kinerja karyawan BPR di Kabupaten Badung

\section{METODE PENELITIAN}

Berdasarkan penelitian yang peneliti lakukan, maka desain penelitian yang digunakan dalam penelitian ini adalah sebagai berikut:

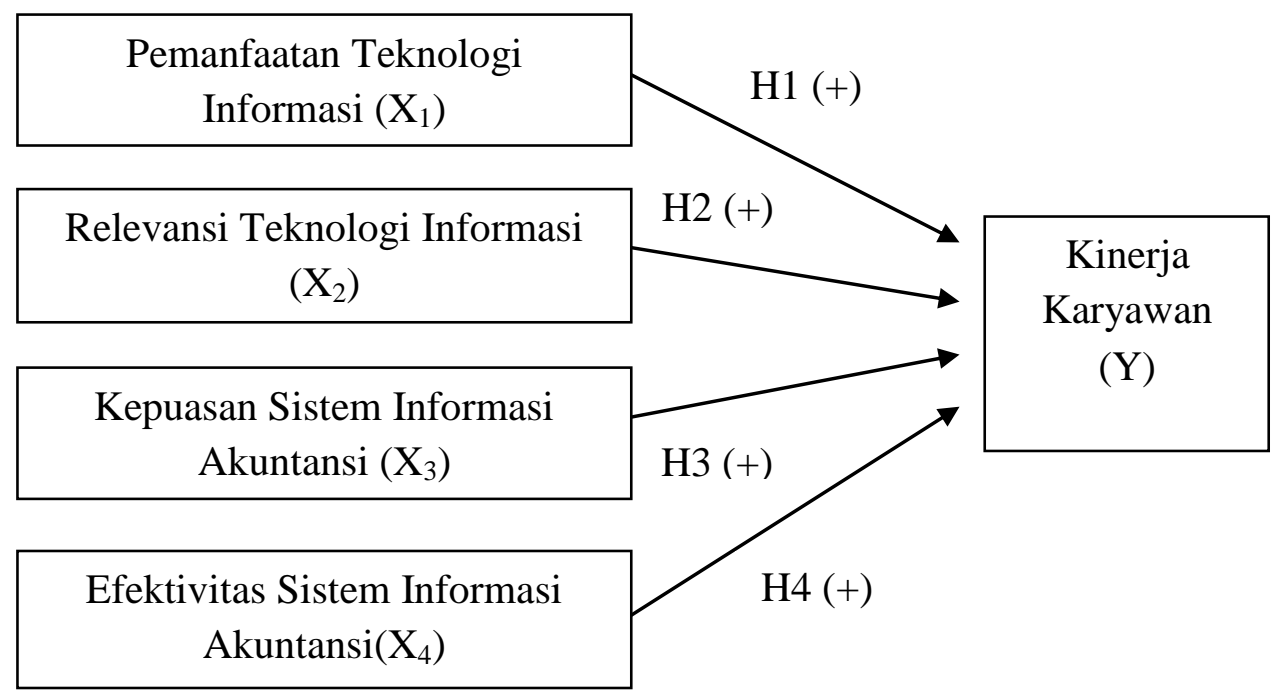

\section{Gambar 1. Desain Penelitian}

Lokasi penelitian yaitu dilakukan di BPR yang terletak di Kabupaten Badung. Obyek penelitian pada penelitian ini yakni mengenai pemanfaatan teknologi informasi, relevansi teknologi informasi, kepuasan sistem informasi akuntansi, efektivitas sistem informasi akuntansi pada kinerja karyawan BPR di Kabupaten Badung. Jenis data yang digunakan dalam penelitian ini yakni, data kuantitatif merupakan data yang berupa angka-angka atau data kualitatif yang diangkakan (Sugiyono, 2014:14). Data kuantitatif dalam penelitian ini adalah data skor nilai dari jawaban kuesioner yang telah diisi oleh responden. Pernyataan yang disajikan dalam kuesioner akan diukur menggunakan skala likert. Dengan menggunakan skala likert, maka variabel yang akan diukur dijabarkan menjadi 
Luh Putu Eka Agustina Pratiwi dan Ida Bagus Dharmadiaksa. Pengaruh...

indikator variabel. Kemudian indikator tersebut dijadikan sebagai titik tolak untuk menyusun item-item instrument yang dapat berupa pernyataan atau pertanyaan (Sugiyono, 2017:93).

Variabel dependen (Y) dalam penelitian ini adalah kinerja karyawan. Kinerja karyawan merupakan pencapaian atau hasil kerja seseorang yang secara keseluruhan selama kurun waktutertentu dalam melaksanakan tugas yang dibandingkan dengan berbagai kemungkinan, seperti standar hasil kerja, target atau sasaran atau kriteria yang telah ditetapkan terlebih dahulu dan telah disepakati bersama. Indikator pengukuran variabel kinerja karyawan yaitu produktivitas, efektivitas, kuantitas kerja, kualitas kerja dan pelayanan sistem komputer yang diadopsi dari penelitian Sugiantara (2017) dengan kuisioner yang telah dimodifikasi olehpeneliti.

Variabel independen dalam penelitian ini adalah pemanfaatan teknologi informasi $\left(\mathrm{X}_{1}\right)$, relevansi teknologi informasi $\left(\mathrm{X}_{2}\right)$, kepuasan sistem informasi akuntansi $\left(\mathrm{X}_{3}\right)$, efektivitas sistem informasi akuntansi $\left(\mathrm{X}_{4}\right)$. Pemanfaaatan teknologi informasi $\left(\mathrm{X}_{1}\right)$ adalah perilaku dalam menggunakan teknologi pada saat melakukan pekerjaan, seperti berapa banyak software yang dikuasai penggunaannya, persepsi atas manfaat software tersebut serta frekuensi penggunaan software tersebut. Adapun indikator pengukuran variabel pemanfaatan teknologi informasi yaitu faktor sosial, affect, kompleksitas, kesesuaian tugas, konsekuensi jangka panjang, dan kondisi yang memfasilitasi yang diadopsi dari penelitian Kasandra (2014). 
Relevansi teknologi informasi atau kesesuaian tugas dengan teknologi informasi $\left(\mathrm{X}_{2}\right)$ merupakan suatu kesesuaian antara teknologi yang digunakan dengan tugas-tugas dan kemampuan pemakai, yang nantinya akan berpengaruh pada peningkatan kinerja karyawan. Adapun indikator pengukuran variabel relevansi teknologi informasi yaitu keakuratan, aksesibilitas, asistensi, tingkat rincian yang tepat dan kemudahan menggunakan perangkat keras dan lunak yang diadopsi dari penelitian Astuti (2014).

Kepuasan pengguna sistem informasi $\left(\mathrm{X}_{3}\right)$ merupakan tingkat kepuasan pemakai terhadap software akuntansi yang digunakan dan output yang dihasilkan oleh software tersebut (Istianingsih dan Setio Hari Wijanto, 2008). Adapun indikator pengukuran variabel kepuasan sistem informasi akuntansi yaitu kelengkapan isi (content), akurat (accuracy), tampilan (format), kemudahan (ease of use), ketepatan (timeliness) yang diadopsi dari penelitian Nurhapsari (2013).

Efektivitas SIA $\left(\mathrm{X}_{4}\right)$ adalah suatu keberhasilan atas penggunaan SIA dalam menghasilkan informasi yang berkualitas sehingga dapat mendukung pengambilan keputusan yang tepat bagi suatu organisasi (Sugiantara, 2017). Adapun indikator pengukuran variabel efektivitas sistem informasi akuntansi yaitu keamanan data, waktu, ketelitian, relevansi, dan variasi laporan yang diadopsi dari penelitian Sugiantara (2017).

\section{HASIL DAN PEMBAHASAN}

Menguji instrumen penelitian dilakukan uji validitas dan uji reliabilitas sebelum data di analisis lebih lanjut. 
Tabel 2

Hasil Uji Validitas

\begin{tabular}{|c|c|c|c|c|}
\hline No. & Variabel & $\begin{array}{c}\text { Kode } \\
\text { Instrumen }\end{array}$ & $\begin{array}{c}\text { Nilai Pearson } \\
\text { Correlation }\end{array}$ & Keterangan \\
\hline \multirow[t]{6}{*}{1} & Pemanfaatan Teknologi & $\mathrm{X}_{1.1}$ & 0,909 & Valid \\
\hline & Informasi $\left(\mathrm{X}_{1}\right)$ & $\mathrm{X}_{1.2}$ & 0,871 & Valid \\
\hline & & $\mathrm{X}_{1.3}$ & 0,798 & Valid \\
\hline & & $\mathrm{X}_{1.4}$ & 0,922 & Valid \\
\hline & & $\mathrm{X}_{1.5}$ & 0,810 & Valid \\
\hline & & $\mathrm{X}_{1.6}$ & 0,873 & Valid \\
\hline \multirow[t]{5}{*}{2} & Relevansi Teknologi & $\mathrm{X}_{2.1}$ & 0,909 & Valid \\
\hline & Informasi $\left(\mathrm{X}_{2}\right)$ & $\mathrm{X}_{2.2}$ & 0,898 & Valid \\
\hline & & $\mathrm{X}_{2.3}$ & 0,886 & Valid \\
\hline & & $\mathrm{X}_{2.4}$ & 0,895 & Valid \\
\hline & & $\mathrm{X}_{2.5}$ & 0,838 & Valid \\
\hline \multirow[t]{5}{*}{3} & Kepuasan Sistem Informasi & $\mathrm{X}_{3.1}$ & 0,970 & Valid \\
\hline & Akuntansi $\left(\mathrm{X}_{3}\right)$ & $\mathrm{X}_{3.2}$ & 0,937 & Valid \\
\hline & & $\mathrm{X}_{3,3}$ & 0,936 & Valid \\
\hline & & $X_{3.4}$ & 0,847 & Valid \\
\hline & & $\mathrm{X}_{3.5}$ & 0,943 & Valid \\
\hline \multirow[t]{5}{*}{4} & Efektivitas Sistem Informasi & $\mathrm{X}_{4.1}$ & 0,837 & Valid \\
\hline & Akuntansi $\left(\mathrm{X}_{4}\right)$ & $\mathrm{X}_{4.2}$ & 0,959 & Valid \\
\hline & & $X_{4.3}$ & 0,869 & Valid \\
\hline & & $\mathrm{X}_{4.4}$ & 0,940 & Valid \\
\hline & & $\mathrm{X}_{4.5}$ & 0,978 & Valid \\
\hline \multirow[t]{5}{*}{5} & Kinerja Karyawan (Y) & $\mathrm{Y}_{1}$ & 0,918 & Valid \\
\hline & & $\mathrm{Y}_{2}$ & 0,910 & Valid \\
\hline & & $\mathrm{Y}_{3}$ & 0,950 & Valid \\
\hline & & $\mathrm{Y}_{4}$ & 0,906 & Valid \\
\hline & & $\mathrm{Y}_{5}$ & 0,919 & Valid \\
\hline
\end{tabular}

Sumber:Data diolah, 2017

Berdasarkan uji validitas yangdilakukan diketahui bahwa Pearson correlation dari masing-masing pernyataan dalam kuisioner lebih besar dari 0,30 .

Hal ini berarti seluruh pernyataan dalam kuesioner telah memenuhi syarat valid sehingga layak digunakan dalam penelitian.

Tabel 3

\section{Hasil Uji Reliabilitas}

\begin{tabular}{clcc}
\hline No & \multicolumn{1}{c}{ Variabel } & Cronbach's Alpha & Keterangan \\
\hline 1 & Pemanfaatan Teknologi Informasi $\left(\mathrm{X}_{1}\right)$ & 0,930 & Reliabel \\
2 & Relevansi Teknologi Informasi $\left(\mathrm{X}_{2}\right)$ & 0,930 & Reliabel \\
3 & Kepuasan Sistem Informasi Akuntansi $\left(\mathrm{X}_{3}\right)$ & 0,959 & Reliabel \\
4 & Efektivitas Sistem Informasi Akuntansi $\left(\mathrm{X}_{4}\right)$ & 0,953 & Reliabel \\
5 & Kinerja Karyawan $(\mathrm{Y})$ & 0,955 & Reliabel \\
\hline
\end{tabular}


Begitu pula dengan hasil uji reliabilitas yang mendapatkan hasil koefisien Cronbach's Alpha lebih besar dari 0,70 sehingga dapat dikatakan reliabel dan layak digunakan dalam penelitian. Hal ini berarti apabila dilakukan pengukuran lebih dari satu kali terhadap gejala yang sama maka pengukuran tersebut akan memberikan hasil yang konsisten.

\section{Tabel 4}

Hasil Uji Statistik Deskriptif

\begin{tabular}{|c|c|c|c|c|c|}
\hline Variabel & $\mathbf{N}$ & Min & Maks & Mean & $\begin{array}{c}\text { Std. } \\
\text { Deviation }\end{array}$ \\
\hline Pemanfaatan Teknologi Informasi $\left(\mathrm{X}_{1}\right)$ & 101 & 2,00 & 4,00 & 3,2787 & 0,56828 \\
\hline Relevansi Teknologi Informasi $\left(\mathrm{X}_{2}\right)$ & 101 & 2,00 & 4,00 & 3,3327 & 0,56305 \\
\hline $\begin{array}{l}\text { Kepuasan Sistem Informasi Akuntansi } \\
\left(\mathrm{X}_{3}\right)\end{array}$ & 101 & 2,00 & 4,00 & 3,4337 & 0,66337 \\
\hline $\begin{array}{l}\text { Efektivitas Sistem Informasi } \\
\text { Akuntansi }\left(\mathrm{X}_{4}\right)\end{array}$ & 101 & 2,00 & 4,00 & 3,3941 & 0,60429 \\
\hline Kinerja Karyawan (Y) & 101 & 2,00 & 4,00 & 3,4099 & 0,61147 \\
\hline Valid N (listwise) & 101 & & & & \\
\hline
\end{tabular}

Sumber: Data diolah, 2017

Pemanfaatan teknologi informasi memiliki nilai minimum sebesar 2,00 nilai maksimum sebesar 4,00 nilai rata-ratanya sebesar 3,2787 dan standar deviasi sebesar 0,56828. Nilai rata-rata 3,2787 menunjukkan secara rata-rata jawaban responden mengarah ke nilai maksimum yang artinya tingkat pemanfaatan teknologi informasi cukup tinggi.

Relevansi Teknologi Informasi $\left(\mathrm{X}_{2}\right)$ memiliki nilai minimum dan maksimum sebesar 2,00 dan 4,00. Rata-rata sebesar 3,3327 dan standar deviasi sebesar 0,56305. Nilai rata-rata sebesar 3,3327 menunjukkan secara rata-rata jawaban responden mengarah ke nilai maksimum yang artinya tingkat relevansi teknologi informasi cukup tinggi. 
Luh Putu Eka Agustina Pratiwi dan Ida Bagus Dharmadiaksa. Pengaruh...

Kepuasan Sistem Informasi Akuntansi $\left(\mathrm{X}_{3}\right)$ memiliki nilai minimum dan maksimum sebesar 2,00 dan 4,00. Rata-rata sebesar 3,4337 dan dan standar deviasi sebesar 0,66337. Nilai rata-rata sebesar 3,4337 menunjukkan bahwa secara rata-rata jawaban responden mengarah ke nilai maksimum yang artinya tingkat kepuasan sistem informasi akuntansi cukup tinggi.

Efektivitas Sistem Informasi Akuntansi $\left(\mathrm{X}_{4}\right)$ memiliki nilai minimum dan maksimum sebesar 2,00 dan 4,00. Rata-rata sebesar 3,3941 dan standar deviasi sebesar 0,60429. Nilai rata-rata sebesar 3,3941 menunjukkan bahwa secara rataratajawaban responden mengarah ke nilai maksimum yang artinya tingkat efektivitas sistem informasi akuntansi cukup tinggi.

Kinerja Karyawan (Y) memiliki nilai minimum dan maksimum sebesar 2,00 dan 4,00. Rata-rata sebesar 3,4099 dan standar deviasi sebesar 0,61147. Nilai rata-rata sebesar 3,4099 menunjukkan bahwa secara rata-rata jawaban responden mengarah ke nilai maksimum yang artinya tingkat kinerja karyawan cukup tinggi. Selanjutnya dilakukan uji asumsi klasik yang meliputi uji normalitas, uji multikolinieritas dan uji heteroskedastisitas untuk mengetahui apakah data dalam penelitian yang dilakukan telah lolos dari asumsi klasik.

\section{Tabel 5}

\section{Hasil Uji Normalitas}

\begin{tabular}{lc}
\hline \multicolumn{1}{c}{ Kolmogorov-Smirnov } & Unstandardized Residual \\
\hline $\mathrm{N}$ & 101 \\
Asymp.Sig.(2-tailed) & 0,074 \\
\hline
\end{tabular}

Sumber: Data diolah, 2017

Nilai Asymp. Sig. (2-tailed) dari model persamaan yang diuji sebesar 0,074 lebih besar dari 0,05. Hasil ini mencerminkan bahwa data yang digunakan 
ISSN: 2302-8556

E-Jurnal Akuntansi Universitas Udayana

Vol.23.1. April (2018): 351-378

dalam penelitian ini berdistribusi normal. Uji asumsi klasik selanjutnya adalah uji multikolinieritas.

Tabel 6

Hasil Uji Multikolinearitas

\begin{tabular}{lcc}
\hline \multicolumn{1}{c}{ Variabel } & Tolerance & VIF \\
\hline Pemanfaatan Teknologi Informasi $\left(\mathrm{X}_{1}\right)$ & 0,414 & 2,418 \\
Relevansi Teknologi Informasi $\left(\mathrm{X}_{2}\right)$ & 0,400 & 2,498 \\
Kepuasan Sistem Informasi Akuntansi $\left(\mathrm{X}_{3}\right)$ & 0,435 & 2,297 \\
Efektivitas Sistem informasi Akuntansi $\left(\mathrm{X}_{4}\right)$ & 0,437 & 2,287 \\
\hline
\end{tabular}

Sumber: Data diolah, 2017

Berdasarkan hasil pengujian, dapat dilihat bahwa nilai tolerance semua variabel lebih besar dari 10\% dan nilai VIF semua variabel kurang dari 10 . Dengan hasil tersebut dapat disimpulkan bahwa data dalam penelitian ini tidak terjadi gejala multikolinearitas.

Uji asumsi klasik yang terakhir adalah uji heteroskedastisitas yang bertujuan mengujiapakah dalam model regresi terjadi ketidaksamaan variance dari residual satu pengamatan ke pangamatan yang lain. Untuk mendeteksi ada atau tidaknya heteroskedastisitas dapat dilakukan dengan uji Glejser dengan meregresikan nilai absolute residual sebagai variabel terikat dengan variabel bebas.

Tabel 7

Hasil Uji Heteroskedastisitas

\begin{tabular}{lcl}
\hline \multicolumn{1}{c}{ Variabel } & Sig. & Keterangan \\
\hline Pemanfaatan Teknologi Informasi $\left(\mathrm{X}_{1}\right)$ & 0,869 & Bebas heteroskedastisitas \\
Rlevansi Teknologi Informasi $\left(\mathrm{X}_{2}\right)$ & 0,232 & Bebas heteroskedastisitas \\
Kepuasan Sistem Informasi Akuntansi $\left(\mathrm{X}_{3}\right)$ & 0,822 & Bebas heteroskedastisitas \\
Efektivitas Sistem Informasi Akuntansi $\left(\mathrm{X}_{4}\right)$ & 0,236 & Bebas heteroskedastisitas \\
\hline
\end{tabular}

Sumber: Data diolah, 2017 
Luh Putu Eka Agustina Pratiwi dan Ida Bagus Dharmadiaksa. Pengaruh...

Setelah diuji diketahui bahwa seluruh variabel independen pada penelitian ini yaitu pemanfaatan teknologi informasi, relevansi teknologi informasi, kepuasaan sistem informasi akuntansi, efektivitas sistem informasi akuntansi menunjukkan nilai sig. masing-masing sebesar 0,$869 ; 0,232 ; 0,822 ;$ dan 0,236 > 0,05. Berdasarkan hasil pengujian, tingkat signifikansi semua variabel berada diatas 0,05 . Jadi, dapat disimpulkan bahwa model regresi tidak mengandung adanya heteroskedastisitas.

Tabel 8

Hasil Analisis Regresi Linier Berganda

\begin{tabular}{|c|c|c|c|c|c|c|}
\hline \multirow{2}{*}{\multicolumn{2}{|c|}{ Model }} & \multicolumn{2}{|c|}{$\begin{array}{c}\text { Unstandardized } \\
\text { Coefficients }\end{array}$} & \multirow{2}{*}{$\begin{array}{c}\begin{array}{c}\text { Standardized } \\
\text { Coefficients }\end{array} \\
\text { Beta } \\
\end{array}$} & \multirow[t]{2}{*}{$\mathbf{T}$} & \multirow[t]{2}{*}{ Sig. } \\
\hline & & $\mathbf{B}$ & Std. Error & & & \\
\hline \multirow[t]{8}{*}{1} & (Constant) & $-0,297$ & 0,881 & & $-0,337$ & 0,737 \\
\hline & $\mathrm{X}_{1}$ & 0,267 & 0,067 & 0,298 & 3,997 & 0,000 \\
\hline & $\mathrm{X}_{2}$ & 0,203 & 0,081 & 0,191 & 2,521 & 0,013 \\
\hline & $\mathrm{X}_{3}$ & 0,195 & 0,071 & 0,199 & 2,741 & 0,007 \\
\hline & $\mathrm{X}_{4}$ & 0,336 & 0,074 & 0,327 & 4,508 & 0,000 \\
\hline & Adjusted $\mathrm{R}^{2}$ & 0,770 & & & & \\
\hline & F hitung & 84,793 & & & & \\
\hline & Signifikansi F & $0,000^{\mathrm{b}}$ & & & & \\
\hline \multicolumn{4}{|c|}{ a. Dependent Variable: Y } & & & \\
\hline
\end{tabular}

Berdasarkan hasil analisis regresi linear berganda pada Tabel 8, maka dapat dirumuskan persamaan regresinya sebagai berikut:

$$
Y=-0,297+0,267 X_{1}+0,203 X_{2}+0,195 X_{3}+0,336 X_{4}+e
$$

Hasil yang diperoleh dari persamaan regresi linier berganda di atas menunjukan besar dan arah pengaruh masing-masing variabel bebas pada variabel terikatnya. Koefisien regresi yang memiliki nilai positif berarti memiliki pengaruh yang searah. Nilai konstanta sebesar -0,297. Ini berarti apabila variabel 
pemanfaatan teknologi informasi $\left(\mathrm{X}_{1}\right)$, relevansi TI $\left(\mathrm{X}_{2}\right)$, kepuasan sistem informasi akuntansi $\left(\mathrm{X}_{3}\right)$, efektivitas sistem informasi akuntansi $\left(\mathrm{X}_{4}\right)$ bernilai nol, maka kinerja karyawan (Y) menurun sebesar 0,297satuan. Nilai koefisien regresi dari pemanfaatan teknologi informasi $\left(\mathrm{X}_{1}\right)$ sebesar 0,267 menunjukkan bahwa variabel pemanfaatan teknologi informasi $\left(\mathrm{X}_{1}\right)$ mempunyai pengaruh positif pada kinerja karyawan (Y) sebesar 0,267. Ini berarti apabila pemanfaatan teknologi informasi naik sebesar 1 satuan dengan anggapan bahwa variabel bebaslainnya konstan, maka kinerja karyawan akanmengalami peningkatan sebesar 0,267 satuan. Nilai koefisien regresi dari relevansi teknologi informasi $\left(\mathrm{X}_{2}\right)$ sebesar 0,203 menunjukan bahwa variabel relevansi teknologi informasi $\left(\mathrm{X}_{2}\right)$ mempunyai pengaruh positif pada kinerja karyawan (Y) sebesar 0,203. Ini berarti apabila relevansi teknologi informasi naiksebesar 1 satuan dengan anggapan bahwavariabel bebas lainnya konstan, maka kinerja karyawan akan mengalami peningkatan sebesar 0,203 satuan.

Nilai koefisien regresi dari kepuasan sistem informasi akuntansi $\left(\mathrm{X}_{3}\right)$ sebesar 0,195 menunjukan bahwa variabel kepuasan sistem informasi akuntansi $\left(\mathrm{X}_{3}\right)$ mempunyai pengaruh positif pada kinerja karyawan $(\mathrm{Y})$ sebesar 0,195. Ini berarti apabila kepuasaan sistem informasi akuntansi naik sebesar 1 satuan dengan anggapan bahwa variabel bebaslainnya konstan, maka kinerja karyawan akan mengalami peningkatan sebesar 0,195 satuan. Nilai koefisien regresi dari efektivitas sistem informasi akuntansi $\left(\mathrm{X}_{4}\right)$ sebesar 0,336 menunjukan bahwa variabel efektivitas sistem informasi akuntansi $\left(\mathrm{X}_{4}\right)$ mempunyai pengaruh positif pada kinerjakaryawan (Y) sebesar 0,336. Ini berarti apabila efektivitas sistem 
Luh Putu Eka Agustina Pratiwi dan Ida Bagus Dharmadiaksa. Pengaruh...

informasi akuntansi naik sebesar 1 satuan dengan anggapan bahwa variabel bebas lainnya konstan, maka kinerja karyawan akan mengalami peningkatan sebesar 0,336 satuan.

Berdasarkan hasil uji kelayakan model pada Tabel 8 di atas, dapat dilihat bahwa nilai $p$-value (Sig. F) yakni 0,000 lebih kecil dari nilai $\alpha=0,05$. Hal ini menunjukkan bahwa model yang digunakan dalam penelitian ini layak untuk diteliti.

Selanjutnya dilakukan uji koefisien determinasi, yang digunakan untuk mengukur seberapa jauh kemampuan semua variabel bebas dalam menerangkan variasi dari variabel dependennya (Ghozali, 2011:95). Dalam penelitian ini koefisien determinasi dilihat melalui adjusted $R^{2}$. Adapun nilai dari adjusted $R^{2}$ pada penelitian ini telah disajikan pada tabel 8. Pada Tabel 8 dapat dilihat bahwa nilai dari adjusted $R^{2}$ sebesar 0,770 dimana memiliki arti bahwa $77 \%$ variasi perubahan kinerja karyawan yang dipengaruhi variasi pemanfaatan teknologi informasi, relevansi teknologi informasi, kepuasan sistem informasi akuntansi, efektivitas sistem informasi akuntansi dan sisanya dijelaskan oleh variabel lain diluar model.

Uji hipotesis atau uji t dilakukan untuk mengetahui pengaruh satu variabel independen secara individual dalam menerangkan variasi variabel dependennya. Uji ini dilakukan dengan membandingkan hasil nilai signifikan dengan $\alpha=0,05$. Berdasarkan hasil penelitian yang ditunjukkan pada Tabel 8, menunjukkan bahwa tingkat signifikansi pemanfaatan teknologi informasi $\left(\mathrm{X}_{1}\right)$ sebesar 0,000 lebih kecil dari nilai $\alpha=0,05$. Hal ini menunjukkan bahwa hipotesis pertama $\left(\mathrm{H}_{1}\right)$ 
diterima yaitu, pemanfaatan teknologi informasi berpengaruh positif pada kinerja karyawan yang berarti adanya hubungan yang searah antara pemanfaatan teknologi informasi pada kinerja karyawan. Jadi, semakin tinggi tingkat pemanfaatan teknologi informasi, maka semakin meningkat pula kinerja karyawan BPR di Kabupaten Badung. Teknologi menjadi salah satu kebutuhan bagi sebuah instansi dalam memudahkan penyelesaian pekerjaan karyawan. Semakin banyaknya fasilitas pendukung yang disediakan bagi pemakai maka akan semakin memudahkan pemakai mengakses data yang digunakan dalam menyelesaikan tugas individu pada perusahan atau organisasi sehingga dapat menghasilkan output lebih baik dan kinerja yang dihasilkan tentunya akan meningkat. Hasil penelitian ini sesuai dengan hasil penelitian yang dilakukan oleh Utari (2012), Astuti (2014), dan Arsiningsih (2015) menyatakan bahwa pemanfaatan teknologi informasi berpengaruh positif terhadap kinerja individu.

Kemudian untuk uji hipotesis kedua berdasarkan Tabel 8 diperoleh tingkat signifikansi relevansi teknologi informasi $\left(\mathrm{X}_{2}\right)$ sebesar 0,013 lebih kecil dari nilai $\alpha=0,05$. Hal ini menunjukkan bahwa hipotesis kedua $\left(\mathrm{H}_{2}\right)$ diterima yaitu relevansi teknologi informasi berpengaruh positif pada kinerja karyawan yang berarti adanya hubungan yang searah antara relevansi teknologi informasi pada kinerja karyawan. Jadi, semakin tinggi tingkat relevansi teknologi informasi maka semakin meningkat pula kinerja karyawan BPR di Kabupaten Badung. Hasil penelitian ini sesuai dengan hasil penelitian sebelumnya yang dilakukan oleh Ashianti (2013) menyatakan bahwa kesesuaian tugas-teknologi memiliki pengaruh positif terhadap kinerja individu. Dengan adanya relevansi teknologi 
Luh Putu Eka Agustina Pratiwi dan Ida Bagus Dharmadiaksa. Pengaruh...

informasi tentu tugas-tugas yang diberikan dapat terselesaikan dengan tepat waktu sehingga akan mempengaruhi kecepatan dan ketepatan seorang karyawan. Kesesuaian tugas yang sesuai dengan keahlian penggunaan teknologi informasi akan meningkatkan kemampuan teknis karyawan (Astuti, 2014). Hasil penelitian yang dilakukan oleh Astuti (2014) dan Sugiantara (2017) menyatakan bahwa kesesuaian tugas dengan teknologi informasi berpengaruh positif terhadap kinerja individual.

Uji hipotesis ketiga sesuai dengan Tabel 8 menemukan hasil bahwa tingkat signifikansi kepuasan sistem informasi akuntansi $\left(\mathrm{X}_{3}\right)$ sebesar 0,007 lebih kecil dari nilai $\alpha=0,05$. Hal ini menunjukkan bahwa hipotesis ketiga $\left(\mathrm{H}_{3}\right)$ diterima yaitu kepuasan sistem informasi akuntansi berpengaruh positif pada kinerja karyawan yang berarti adanya hubungan yang searah antara kepuasan sistem informasi akuntansi pada kinerja karyawan. Jadi, semakin tinggi tingkat kepuasaan sistem informasi akuntansi, maka semakin meningkat pula kinerja karyawan BPR di Kabupaten Badung. Adanya keterlibatan secara langsung dari pengguna dalam mengoperasikan sistem informasi, tentu akan memberikan manfaat dan kemudahan penggunaan sistem tersebut. Hal ini pada akhirnya akan membuat pengguna merasa puas atas kualitas informasi yang dihasilkan karena memenuhi kriteria akurat, tepat waktu, relevan, mudah di pahami sehingga pada akhirnya dapat membantu kinerja dari individu. Hasil penelitian ini sejalan dengan hasil penelitian yang dilakukan oleh Wijayanti (2013) dan Raminda (2014) yang menyatakan bahwa kepuasan pengguna berpengaruh positif terhadap kinerja individual. 
Kemudian untuk uji hipotesis keempat, berdasarkan hasil penelitian yang ditunjukkan pada Tabel 8 didapatkan nilai tingkat signifikansi efektivitas sistem informai akuntansi $\left(\mathrm{X}_{4}\right)$ sebesar 0,000 lebih kecil dari nilai $\alpha=0,05$. Hal ini menunjukkan bahwa hipotesis keempat $\left(\mathrm{H}_{4}\right)$ diterima yaitu efektivitas sistem informasi akuntansi berpengaruh positif pada kinerja karyawan yang berarti adanya hubungan yang searah antara efektivitas sistem informasi akuntansi pada kinerja karyawan. Jadi, semakin tinggi tingkat efektivitas sistem informasi akuntansi, maka semakin meningkat pula kinerja karyawan BPR di Kabupaten Badung. Sistem informasi akuntansi sangat berpengaruh dalam menunjang produktivitas perusahan. Perusahan diyakini dapat melakukan proses operasi maupun informasi dengan yang lebih efektif dan efesien dengan adanya sistem informasi akuntansi sehingga hasil yang dicapai dapat sesuai dengan tujuan perusahan. Hasil penelitian ini sejalan dengan hasil penelitian yang dilakukan oleh Suratini (2015) dan Antasari (2015) dan Wirawan dan Suardikha (2016) yang menyatakan bahwa efektivitas sistem informasi akuntansi berpengaruh positif terhadap kinerja individual.

Berdasarkan pembahasan yang telah diuraikan diatas, terdapat beberapa implikasi dalam bidang akademisi dan penelitian selanjutnya serta para praktisi untuk: (a) Bagi penulis, dapat memberikan bukti empiris tentang pengaruh pemanfaatan teknologi informasi, relevansi teknologi informasi, kepuasan sistem informasi akuntansi dan efektivitas sisteminformasi akuntansi pada kinerja karyawan BPR di Kabupaten Badung. Disamping itu, pada penelitian ini dijadikan sebagai sarana dalam menerapkan dan mempraktekan ilmu pengetahuan yang 
diperoleh selama duduk dibangku kuliah dan membandingkannya dengan keadaan di lapangan. (b) Bagi pihak perusahan, hasil penelitian ini dapat memberikan manfaat sebagai masukan dalam pertimbangan pengambilan keputusan tentang faktor-faktor perkembangan dan penilaian kinerja khususnya teknologi sistem informasi akuntansi. (c) Bagi peneliti lain dapat digunakan sebagai bahan referensi dan inspirasi dalam melakukan penelitian selanjutnya. Selain itu penelitian ini dapat memperluas wawasan pengetahuan.

\section{SIMPULAN}

Adapun kesimpulan yang dapat diambil dari penelitian ini meliputi: 1) Pemanfaatan teknologi informasi berpengaruh positif pada kinerja karyawan BPR di Kabupaten Badung. Hal ini berarti semakin tinggi tingkat pemanfaatan teknologi informasi, maka semakin meningkat pula kinerja karyawan BPR di Kabupaten Badung; 2) Relevansi teknologi informasi berpengaruh positif pada kinerja karyawan BPR di Kabupaten Badung. Hal ini berarti semakin tinggi tingkat relevansi teknologi informasi, maka semakin meningkat pula kinerja karyawan BPR di Kabupaten Badung; 3) Kepuasan sistem informasi akuntansi berpengaruh positif pada kinerja karyawan BPR di Kabupaten Badung. Hal ini berarti semakin tinggi tingkat kepuasan sistem informasi akuntansi, maka semakin meningkat pula kinerja karyawan BPR di Kabupaten Badung; 4) Efektivitas sistem informasi akuntansi berpengaruh positif pada kinerja karyawan BPR di Kabupaten Badung. Hal ini berarti semakin tinggi tingkat efektivitas sistem informasi akuntansi, maka semakin meningkat pula kinerja karyawan BPR di Kabupaten Badung. 
Terdapat beberapa hal yang dapat disarankan sesuai dengan hasil pembahasan hingga kesimpulan yang disajikan dalam penelitian ini meliputi: (1) Bagi Bank Perkreditan Rakyat (BPR) sebaiknya mengevaluasi dan membarui sistem informasi akuntansinya agar sistem informasi yang diterapkan dapat sesuai dengan perkembangan dan kebutuhan karyawan. Disamping itu, pihak perusahaan perlu mengadakan training atau pelatihan bagi karyawan apabila terdapat teknologi baru. Dengan dimanfaatkannya teknologi dengan baik maka akan berdampak pada produktivitas perusahan sehingga karyawan mampu untuk menyelesaikan tugasnyaserta memberikan pelayanan yang cepat terhadap nasabah. (2) Bagi peneliti selanjutnya keterbatasan pada penelitian ini hendaknya agar lebih disempurnakan lagi pada penelitian selanjutnya adalah dengan tidak membatasi daerah pengambilan sampel penelitian hanya pada satu Kabupaten saja. Pada penelitian berikutnya diharapkan dapat mereplikasi faktor-faktor lain yang berpengaruh pada kinerja karyawan seperti kemudahan penggunaan sistem informasi, pengembangan sistem, tingkat kepercayaan pemakai, dan tingkat keahlian personal.

\section{REFERENSI}

Agustiani, N. H. (2010). Pengaruh Pemanfaatan Sitem Informasi Akademik Terpadu (SIKADU) Terhadap Kinerja Individual Dengan Kemudahan Penggunaan Sebagai Variabel Moderating. Tesis.

Antasari, Kadek Chendi dan Pt D’yan Yaniartha. 2015. Pengaruh Efektivitas Sistem Informasi Akuntansi dan Penggunaan TeknologiInformasi Pada Kinerja Individual Dengan Kepuasan Kerja Sebagai Variabel Pemoderasi. E-Jurnal Akuntansi Universitas Udayana 10.2 (2015) : 354-369.

Arsiningsih Febri, Ni Luh Putu. 2015. Pengaruh Penggunaan Teknologi Informasi, Efektivitas Sistem Informasi Akuntansi, Kepercayaan atas Sistem 
informasi Akuntansi, Sistem Pengendalian Intern terhadap Kinerja Karyawan pada Bank Perkreditan Rakyat di Kabupaten Buleleng dan Bangli. e-Journal Akuntansi Universitas Pendidikan Ganesha Jurusan Akuntansi Program S1. 3(1).

Ashianti, Agnes. 2013. Pengaruh Kesesuaian Tugas-Teknologi, Kepercayaan dan Efektivitas Sistem Informasi Akuntansi Terhadap Kinerja Individu pada Pasar Swalayan di Kota Tangerang. Ultima Accounting Universitas Multimedia NusantaraVol 5. No.2.

Astuti , Ni Made Marlita, 2014. Pengaruh Efektivitas Penerapan Sistem Informasi Akuntasi, Pemanfaatan dan Kesesuaian Tugas dengan Teknologi Informasi terhadap Kinerja Karyawan pada Koperasi Simpan Pinjam di Kabupaten Gianyar. Skripsi Jurusan Akuntansi Fakultas Ekonomi Universitas Udayana.

Awesejo, O.J., Kekwaletswe, R, M., Pretorius, P and Zuva, T. 2013. The Effect of Accounting Information Systems in Accounting. 3(1), pp: 142-150.

Baig, A. H. and Gururajan, R. 2011. PreliminaryStudy to Investigation the Determinants that Effect IS/IT Outsourcing. Journal of Information and CommunicationTechnologyResearch, 1 (2), pp: 48-54.

Davis, Fred D., Bagozzi Richard P., dan Warshaw Paul R. 1989. UserAcceptance Of Computer Technology: A Comparison TwoTheoretical Models. Journal ManagementScience, Vol. 35, No. 8, hal: 982-1003..

Edison, G., Manuere, F., Joseph, M., and Gutu, K. 2012. Evaluation of Factors Influencing Adoption of Accounting Information System by Small to Medium Enterprises in Chinhoyi. Journal of Contemporary Research in Business, 4(6), pp: 1126-114.

George, Ndemo Ochoti., Elijah, Maronga Dr. Stephen., Muathe Dr. Robert, Nyamao., and Peter, Kibet. 2012. Factors employee performance Appraisal System. Internasional Journal of Business and Social Science. 3(20), pp : $37-46$.

Ghasemi, M., Shafeiepour, V., Aslani, M., \& Barvayeh, E. (2011). The Impact of Information Technology (IT) on Modern Accounting Systems. ProcediaSocial and Behavioral Sciences, 28:112-116.

Ghozali, Imam. 2016. Aplikasi Analisis Multivariate dengan Program SPSS. Semarang: Badan Penerbit Universitas Sumatera Diponegoro.

Goodhue, D.L., and Thompson, R.L. 1995. Task Technology Fit and Individual Performance, MIS Quarterly, pp: 213-236. 
Hall, James A. (Dewi Fitriasari dan denyArnos Kwary, Penerjemah). 2009. Sistem Informasi Akuntansi. Edisi Keempat. Jakarta: Salemba Empat.

Istianingsih dan Setyo Hari Wijanto. 2008. PengaruhKualitas Sistem informasi, Kualitas Informasi, dan Percived Usefulness Terhadap Kepuasan PenggunaSoftware Akuntansi. SimposiumNasional Akuntansi IX Pontianak

Istianingsih dan Utami. 2009. Pengaruh KepuasanPengguna Sistem InformasiTerhadap Kinerja Individu(Studi Empiris Pada Pengguna Paket Program Aplikasi SistemInformasiAkuntansi Di Indonesia).

Jackson Chintya M., Simeon Chow and Leitch Robert A. 1997. Toward Understanding the Behavioral Intention to Use an Information Sistem. Decision Sciences, 28(2), pp: 357- 389.

Jogiyanto, H.2007. Model Kesuksesan Sistem Teknologi Informasi. Andi Pusblisher, Yogyakarta.

Jogiyanto. 2009. Sistem Teknologi InformasiEdisi Ketiga. Yogyakarta. Universitas Gajah Mada.

Jurnali, Teddy dan Bambang Supomo. 2002. Pengaruh Faktor Kesesuaian Tugas Teknologi dan Pemanfaatan Teknologi Informasi Terhadap Kinerja Akuntan Publik. Jurnal Riset Akuntansi Indonesia, 5(2), pp: 214-228.

Jusup, Al. Haryono.2011.Dasar - Dasar Akuntansi Jilid 2.Yogyakarta : Bagian Penerbitan Sekolah Tinggi Ilmu YKPN.

Kasandra, Ni Made Ayu Ari. 2014. Pengaruh Kualitas Penerapan Sistem Informasi Akuntansi, Pemanfaatan dan Kepercayaan Teknologi Informasi Terhadap Kinerja Karyawan pada Bank Perkreditan Rakyat di Kabupaten Tabanan. Skripsi. Jurusan Akuntansi Fakultas Ekonomi dan Bisnis Universitas Udayana.

Kasmir. 2012. Bank dan Lembaga Kuangan Lainnya. Jakarta: PT. Raja Grafindo Persada.

Kelton, Andrea Seaton, Robin R. Pennington dan Brad M.Turtle.2010. The effect of information Presentation Format on Judgement and decision Making: A Review of The Information System Research. Journal of Information System, 24 (2), pp: 79-105.

Kesumman, Pravitri Marga dan I Made Sadha Suardikha. 2016. Penggunaan Sistem Informasi Pengelolaan Keuangan Daerah Terhadap Kinerja Pegawai Pada Satuan Kerja Perangkat Daerah. E-Jurnal Akuntansi Universitas Udayana Vol.15.2. 
Kharuddin, S., Nassir, M.A., and M.Z. Ashhari. 2010. InformationSystem and Firms Performance: The Case of Malaysian Small Medium Enterprise. International bussinessresearch, 3(4), 33.

Kouser, R., Awan, Shahzad, F.,and A., Rana, G. 2011. Firm Size, Leverage and Profitability: Overriding Impact ofAccounting Information System. Journal of Management andBussiness review, 1(10),58-64.

Lucas Henry C. and Spitler V. K. 1999. Technology Use and Performance :

A field Study of Broker Workstation. Decisions Sciences, 30(2), pp: 291311.

Mercika, Ni Luh Dewi Trisna, 2014. Kemudahan Penggunaan Sistem Sebagai Pemoderasi Pengaruh Efektivitas Sistem Informasi Akuntansi Terhadap Kinerja Karyawan PT BPR Sri Artha Lestari Denpasar. Skripsi Jurusan Akuntansi Fakultas Ekonomi dan Bisnis Universitas Udayana.

Nurhapsari, Putri Krisna. 2013. Pengaruh Kualitas Layanan Sistem Informasi, Kualitas Sistem Informasi, dan Kualitas Informasi Terhadap Kepuasan Pengguna Akhir Sistem Informasi (Survei Pada Tiga Satker KPU Pengguna Software Aplikasi SIA). Skripsi Fakultas Ekonomi Universitas Widyatama.

Nwokeji, Emeka N.A. 2012. Repositioning Accounting Information system Through Effective Data Quality Management: A Framework for reducing Cost an Improving Performance. International Journal Of Scientific \& Technology Research Volume 1.

Onaolapo A. A. and Odetayo T.A 2012.Effect Of Accouting Information System on Organi Sational Effectivenss.

Putra, I Kadek Agastia Maha dan I Made Pande Dwiana Putra. 2016. Pengaruh Efektivitas Penggunaan, Kepercayaan, Keahlian Pengguna, Dan Kualitas Sistem Informasi Akuntansi Terhadap Kinerja Karyawan. E- Jurnal Akuntansi Universitas Udayana Vol. 17, No. 2

Rahmawati, Diana. 2008. Analisis Faktor Faktoryang Berpengaruh Terhadap Pemanfaatan TeknologiInformasi. Jurnal Ekonomi dan Pendidikan, 5 (1), h: 107-118.

Raminda, All Natri Ayu dan Lilis Ardiani. 2014. Pengaruh Kualitas Sistem, Kualitas Informasi Dan Kepuasan Pengguna Accurate Terhadap Kinerja Individu. Jurnal Ilmu \& Riset Akuntansi STIESIASurabayaVol. 3 No. 9 (2014). 
Romney, M. B., \& Steinbart, P.J. (2011). Accounting Information Systema $\left(9^{\text {th }}\right.$ ed). England: Pearson Education.

Rosanty, Ade Diana, dkk. 2017. Pengaruh Teknologi Sistem Informasi Akuntansi, Kualitas Sistem Informasi Dan Kepuasan Pengguna Terhadap Kinerja Organisasi Pada Dinas Kebudayaan Dan Pariwisata Kabupaten Buleleng. EJournal S1 Ak Universitas Ganesha,Vol: 8 No: 2.

Sajady. H., Dastgir and H. Hashem Nejad. 2008.Evaluation The Effectivenessof Accounting Information System. International Journal ofInformation Science and Technology. 6(2). pp: 49-59.

Salamah, Irma. 2012. Utilization of IT and the Effects on Individual Performance of Lecturers at State Polytechnic Sriwijaya. Dalam Journal of Economics, Business, and Accountancy Ventura Vol. 15, No. 1, April 2012, hal. 31-46.

Siregar, Astuti Handayani dan I Ketut Suryanawa. 2009. Pemanfaatan Teknologi Informasi dan Pengaruhnya Pada Kinerja Individual Pada Kantor Pelayanan Pajak Pratama Denpasar Barat. E-Journal Akuntansi Universitas Udayana, h:1-24.

Soudani, Siamak Nejadhosseini. 2012. TheUsefulness of an Accounting Information System for EffectiveOrganizational Performance. Internasional Journal of Economics and Finance. 4(5) pp: 136-143.

Sugiantara, Pande Putu Oka dan Putra, I Md Pande Dwiana. 2017. Analisis Faktor-Faktor Yang Mempengaruhi Kinerja Karyawan Di Dispenda Kota Denpasar. E-Jurnal Akuntansi Universitas Udayana Vol.20 No.3.

Sugiyono.2017. Metode Penelitian Kuantitatif, Kualitatif dan R\&D. Bandung : Alfabeta.

Supriyanto, Aji. 2005. Pengantar Teknologi Informasi. Jakarta: Salemba Infotek.

Suratini, Eka, dkk. 2015. Pengaruh Efektivitas Sistem Informasi Akuntansi Dan Penggunaan Teknologi Informasi Akuntansi terhadap Kinerja Individual Pada PT. Bank Pembangunan Daerah Bali Kantor Cabang Singaraja. EJournal Akuntansi Program S1Universitas Pendidikan Ganesha, Vol. 3, No. 1, hal 1-10.

Tjhai Fung Jin. 2003. Analisis Faktor-faktor yang Mempengaruhi Pemanfaatan Teknologi Informasi dan Pengaruh Pemanfaatan Teknologi Informasi terhadap Kinerja Akuntan Publik. Dalam Jurnal Bisnis dan Akuntansi, 5(1):1-26. 
Trigo, António, Fernando Belfo and Raquel Pérez Estébanez. 2016. Accounting Information Systems: evolvingtowards a business process oriented accounting. ProcediaComputer Science 100 ( 2016 ) 987 - 994.

Urquia, Grande E., Munoz, Columbia C., and Estebanez, Raquel P. 2011. The Impact of Accounting Information System (AIS) on Performance Measures: Empiricial Evidencein Spanish SMEs1. The International Journal of Digital Accounting Research, 11,25-4.

Utami, Nyoman Ayu Devi Sri, dkk. 2015. Pengaruh Pemanfaatan Teknologi, Pelatihan, dan Partisipasi Pemakai Terhadap Efektivitas Implementasi Sistem Informasi Akuntansi (Studi Empiris pada BPR di Kabupaten Buleleng). E-journal SI Ak Universitas Ganesha, Vol.3, No.1.

Utari, Putu Sariyanthi. 2012. PengaruhEfektivitas Sistem Informasi Akuntansi, KepercayaanTeknologi Informasi dan Pemanfaatan TeknologiInformasi Terhadap Kinerja Individu Pada Koperasi SimpanPinjam di Kecamatan Denpasar Selatan. Skripsi FakultasEkonomi Universitas Udayana.

Wahyuni, Ika. 2014. Faktor-faktor PemanfaatanTeknologi Informasi dan PengaruhnyaTerhadap Kinerja Para Pemakai Enterprise Resource Planning (ERP) di PT Semen Tonasa. Skripsi Fakultas Ekonomidan Bisnis Universitas Hasanuddin Makassar.

Wijayanti, Tutut. 2013. Pengaruh Teknologi Sistem Informasi Akuntansi, Kepercayaan Teknologi Sistem Informasi Akuntansi, Dan Kepuasan Pengguna Terhadap Kinerja Individual (Studi Pada Dinas Pendapatan Pengelolaan Keuangan Daerah Dan Aset Daerah (Dppkad) Kabupaten Grobogan). Skripsi Fakultas Ekonomi Dan BisnisUniversitas Muhammadiyah Surakarta.

Williams, Brian andSawyer, Stacey C.2005. Using Information Technology Practical Introduction to Computers \&Communications. McGrawHill, New York, USA.

Wirawan, Bima Satya dan I Made Sadha Suardikha. 2016. Faktor - faktor yang Mempengaruhi Kinerja Individual Pada Bank Perkreditan Rakyat di Kabupaten Badung. E-jurnal akuntansi Universitas Udayana Vol. 17.3

Yunita, Nurhayati. 2012. Analisis Faktor-faktor yang Mempengaruhi Kinerja Sistem Informasi Akuntansi Pada Minimarket Di Wilayah Jakarta. Jurnal Akuntansi. Universitas Gunadarma.

Zare, I. 2012. Studyof Effect of Accounting Information System and Softwares on Qualitative Features of Accounting Information. Journal of Management Science and BusinessResearch, 1 (4), pp: 1-12. 